\title{
Increasing the Value of Tourism of Tangga Buntung Musi River Banks, South Sumatra as Tourism Destination Through English for Tourism Training Program
}

\author{
Muhammad Arif Ramadhan \\ Department of Hospitality and Tourism \\ Sekolah Tinggi Pariwisata \\ Jakarta, Indonesia \\ rifardian196@gmail.com
}

\author{
Sheilla Noveta Asmaruddin \\ Department of English Education \\ Universitas Katolik Musi Charitas \\ Palembang, Indonesia
}

\begin{abstract}
The purpose of this paper is to give solutions towards issues that arise within the area of Tangga Buntung Musi River Banks in relation with the development of tourism. Furthemore, this paper highlights several research of developing English Training Program within several communities in Indonesia. One of the main locations that the Government of South Sumatra is developing is Tangga Buntung in relation to 2018 Asian Games preparation and also to improve the decline of tourist visiting Palembang based on Central Bureau of Statistics South Sumatra 2016. It is advisable that the members of the community of Tangga Buntung be trained to support the tourism development in Tangga Buntung. The result of this review is that one of those trainings that is strongly to be set up for the members of the Tangga Buntung community is for them to be given English for Tourism.
\end{abstract}

\section{Keywords-Tourism destination, English training program}

\section{INTRODUCTION}

Tangga Buntung is an area located on the banks of Musi River, Palembang, South Sumatra. This is where the hub for songket craft, a well known traditional cloth of South Sumatra is located. This place has begun since around XVIII century. We can find traditional Palembangnese songket with a very high qualified art value. Furthermore, at Tangga Buntung we can find many well known songket gallery. Among those are Zainal Songket, Cek Ipah, Cek Ilah, Fikri Collection and many more. The majority of the songket craftsmen found in Tangga Buntung are closely related to one another in which their skill of weavery are inherited from one generation to the next. We can conclude that Tangga Buntung is one of a historical sites in South Sumatra that holds cultural and art value which can be potential for tourism destination.

Currently, the Government of South Sumatra is focusing its infrastructure development along the Musi River for Asian Games 2018. Since the Musi River is the main trademark of South Sumatra. This includes Tangga Buntung area due to its function as the Central Songket Industry. However, the members of Tangga Buntung community should also be prepared to become a tourism site. It is important that a certain attitude and behaviour should be adapted. Those are having appropriate hospitality and manners so that tourists visiting Tangga Buntung can feel comfortable and would always want to come back. This situation would give great benefit for the economic growth in South Sumatra. A solution is to give training and workshop of hospitality to the Tangga Buntung community. One of those training that is important is English for Tourism Training Program.

According to Fleisher, $\mathrm{Li}$ and $\mathrm{Li}$ (2015), based on the findings of their research focusing on language investment, it was found that workers with good language proficiency obtain higher income than those who do not invest on language skills for their human resources quality. Kachru (2015) indicated that English is the most spoken language in the world. Hence, it is crucial and considered vital for workers to have English language skills. Especially, in ASEAN region, English is a second language for some countries, yet, in our country English is still a foreign language. This shows that we have to accelerate our English language skill and proficiency.

The purpose of this paper is to promote the importance of teaching English to a community located in Tangga Buntung, Palembang, South Sumatra in relation to support tourism development. Furthemore, this paper highlights several research of developing English Training Program within several communities in Indonesia in relation to support tourism development. There are many tourism destination in Palembang and one of the main locations that the Government of South Sumatra is developing is Tangga Buntung in relation to 2018 Asian Games preparation and also to improve the decline of tourist visiting Palembang based on Central Bureau of Statistics South Sumatra 2016.

Tangga Buntung is one of main tourism destination in Palembang, located in the banks of Musi River. This is the location of hand-made songket, a tradional cloth of South Sumatra. For the vendors of songket located in Tangga Buntung, it is strongly needed for them to be able to communicate in English so that they may be able to promote 
their products. However, the communities living in Tangga Buntung should also be able to accommodate tourists coming to Tangga Buntung to buy songket. Hence, it is vital to set up a community based English training program in Tangga Buntung. A research conducted by Timothy (2014) pointed out that community training can support the local people be involved in tourism improvement.

\section{LITERATURE REVIEW}

\section{A. English for Tourism Training Program}

Widodo and Hastuti (2011) conducted a research to facilitate the English language ability of the souvenirs vendors at Sangiran Museum, Sukaharjo. There were 24 participants in which only two are men. Most of the participants are primary school graduates. It was found that the result of souvenirs that these vendors sold were not satisfying due to the lack of speaking skill in English. Sangiran Museum is one of tourism destinations determined by UNESCO as world heritage list. Hence, many tourist from all over the world are attracted to visit for research, tourism, exploration and study comparison. An English training program established in three stages were set up. Those are practising and demonstrating English conversation; English conversation focusing on buying and selling something; and simulation of taught English conversation that involved real tourists. The result of the research showed that the English training program can improve the participants' speaking skill in English, specifically in selling and offering their souvenirs to tourists.

It can be possible that the research conducted by Widodo and Hastuti (2011) be replicated in the community of Tangga Buntung, Palembang, South Sumatra. The vendors of songket located in Tangga Buntung can gain more profit if they are able to communicate in English in terms of selling and offering their product, in this case songket. Furthermore, this type of English for tourism training program can strongly support the tourism development of South Sumatra. However, if we are to establish an English for Tourism training program in Tangga Buntung, it should also be attended by other members of community to enhance and achieve maximum goal in gaining more tourists to visit Tangga Buntung.

Wijayantiningsih, Mulyadi and Fathurrohman (2015) found out in their research that English Training Program was able to give benefits for the owners of homestay located in Kandiri, a tourism village in Semarang. Since most of the homestay owners have limited background of communicating in English, they needed an English training program so that they are able to give professional and effective service to the tourists visiting Kendari village. The method used in this research was drill and repetition, workshop and community service. Specifically, the owners of home stays in Kendari were taught daily conversation in English. Furthermore, they were provided with Englsih instructions and booklets as a guide to give service in English. From the result of the study, there were a significant increase of English daily conversation ability of the home stay owners. Additionally, a practical guide in English daily conversation was made and the service management of the home stay increased.
Developing homestays in Tangga Buntung, Palembang is an investment that can benefit the community of Tangga Buntung in the long run. It can also help the government of South Sumatra boost its tourism potential since Tangga Buntung is located in the banks of Musi River in which is the main trademark of South Sumatra. Currently, the Government of South Sumatra is in the process of building Musi River 4 which connects Tangga Buntung to the area in 14 Ulu.This indicates that Tangga Buntung is one of economic pockets in Palembang. However, those who operates homestays are strongly advisable to undergo English for Tourism training program. Based on ASEAN Economic for Community, one of priorities is those who are working in the Tourism and Hospitality Industry. Since English is the most spoken language around the world, it is vital that those working in the Tourism and Hospitality industry master the English language, specifically English for Tourism.

Another example of an English for Tourism Training Program had taken place in Goa Pindul, Yogyakarta in 2016. It was an English for Tourism Training Program for Tourist Guides conducted by youth organisation located at Goa Pindul. Ayu (2016) investigated the effectiveness of the English training program through observation, questionnaire and interview. It was observed that the program was successful. There was interactions between the tutors and the twenty four tour guides since a constructive procedure was set. It covered planning: needs analysis, teaching material and needs for training preparation. An evaluation had taken place to know whether the tourists were satisfied with the tourist guides service. The result indicated satisfactory.

\section{METHODS}

\section{A. The Importance of English language competency in supporting to tourism destination}

Tangga Buntung, Palembang has already the elements as creative cluster industry (Drastiani, 2014). Drastiani (2014) strongly recommended that there should be design process in stages between the year 2025-2050. Those are sociability concept, user and activity concept, access and linkages concept and comfort and images concept. The process of this research was commenced with discussing about the eleven characteristics of creative cluster industry elements and nine elements of urban heritage waterfront characteristics located at Ki Rangga Wirasantika, Ki Ged Ind Suro and another located specifically at the bank of the Musi River. The research design was a study case using literature study, audio visual material, observation and qualitative interview as means of collecting data.

Drastiani (2014) concluded that in developing Tangga Buntung as cluster creative industry can be easily applied since based on recommended strategies as mentioned above due to Tangga Buntung already have individual creative potential and sub-area waterfront that can be delevoped well in the near future. Creative individual, songket craftsmen, can strongly support the cluster area industry develop well and continuosly if it is in line with the support of facilities. Meanwhile, the increase of area quality by applying the placemaking and waterfront concept can support the quality of life of the 
creative individuals which can increase the profit for economic growth in Palembang.

Hence, from the result of the research, it is confirm that Tangga Buntung has great potential as cluster creative industry. However, if these concept abide the quality of human recources in the community of Tangga Buntung, the outcome to boost tourism potential in relation to support South Sumatra government is far from satisfactory. Based on the report made by Rosana (2016, para. 1) "tourists visiting Palembang declined 44,79\% in April 2016". Even though from this result we cannot conclude in which sector the decline is, however, we can assume that English for Tourism training program can be one of the ways to boost tourismnpotential.

\section{RESUlT AND DISCUSSION}

\section{A. Strategies in Developing English for Tourism Training Program}

To set up an English for Tourism Training Program for the community of Tangga Buntung, there are several procedures to be followed. Firstly, an appropriate instructors having competence in English language, tourism and hospitality sector, and knowledge of the Tangga Buntung area as tourism destination area. Secondly, determining the curicullum to be taught the community of Tangga Buntung. English for Tourism should be developed not only for the community to learn how to communicate in English language but to know the tourism aspect found in Tangga Buntung, Palembang and be able to present in a manner of hospitality competence. Hence, the value of toursim in Tangga Buntung increases in which can bring positive economic growth not only to the community but for the province of South Sumatra. It is advisable that English for Tourism can help the members of community of Tangga Buntung conduct daily conversation that supports the tourism in Tangga Buntung such as how to sell and promote the products of songket, to be able to explain about the history of songket and Tangga Buntung using appropriate standard hospitality for tourism to foreign tourists coming from all over the world.

It is important for an English for Tourism to be established immediately in Tangga Buntung, Palembang due to two main reasons. Those are the upcoming Asian Games 2018 and the ASEAN Economic Community priorities. South Sumatra has a target to increase tourists visiting Palembang up to $12 \%$ at the event of Asian Games 2018 (Tambak,2016). To support this target, to be able to communicate with the tourist in terms of promoting several area of tourism destination, one of those is Tangga Buntung, the members of the community must be able to have basic knowledge and skill in communiticating in English, specifically English for Tourism. This is used to promote the tourist attraction in the area and to sell the product found in the area. In the case of Tangga Buntung, the songket developed by the craftsment as a high qualified cultural heritage artistry should be promoted appropriately using English language so that the tourists can understand and have interest in purchasing songket.

Another important reason to be considered, tourism is included in the priorites of Economic for ASEAN Economic
Community. It is stated in the blue print of ASEAN Economic Community that the vision for tourism in 2025 is to have a qualified tourism in the ASEAN region in which can be evaluated through the competence of the human recourses in tourism. It is inevitable that English language compentency play a vital role in this sector since it is the language that connects to many people from different culture and background.

\section{REFERENCE}

Ayu, L., A. (2016). Program pelatihan bahasa inggris bagi pemandu objek wisata Goa Pandu di

wirawisata. Jurnal Elektronik Pend. Luar Sekolah - S1, 5(4), $1-11$

Retrieved

from

http://journal.student.uny.ac.id/ojs/index.php/pls/article /view/1390/1264

Drastiani, R. (2014, November). Pengembangan kawasan Tangga Buntung sebagai creative cluster industry di kawasan wisata tepian ilir sungai Musi Palembang. Paper presented at Temu Ilmiah IPLBI 2014. Retrieved from.

http://temuilmiah.iplbi.or.id/wpcontent/uploads/2015/01/TI20 14-B-p023-028-Pengembangan-Kawasan-Tangga-

Buntungsebagai-Creative-Cluster-Industry-diKawasan-Wisata-Tepian-Ilir-Sungai-MusiPalembang.pdf

Kachru, Y. (2015). This issue of World Englishes is dedicated to celebrating the life and work of. World Englishes, $883,2919$.

Li, H., Li, B., \& Fleisher, B. M. (2015). Language skills are critical for workers' human capital transferability among labor markets.

Rosana, D. (2016). Jumlah kunjungan wisatawan di Sumsel merosot. $\quad$ Retrieved from http://www.antarasumsel.com/berita/303690/jumlahkunjungan-wisatawan-di-sumsel-merosot

Ruslan, T. (2016). Ajang Asian Games 2018, Sumsel targetkan wisatawan naik $12 \%$. Retrieved from

http://www.rmol.co/read/2016/02/17/236049/Ajang-AsianGames-2018,-Sumsel-Targetkan-Wisatawan-Naik-12Persen-Timothy, D. J. (2000). Building community awareness of tourism in a developing country destination. Tourism Recreation Research,25(2), 2000. Retrieved from http://www.tandfonline.com/doi/abs/10.1080/02508281 .2000 .11014916

Widodo, Y., \& Hastuti, D.W. (2011). English Conversation bagi Pedagang Souvenir(program ipteks bagi masayarakat kompetitif $(\mathrm{Ibm})$ ). Paper presented at LPPM Universitas Veteran Bangun Nusantara 
Sukaharjo 2011.Retrieved from http://lppmbantara.com/yoto04.html.

Wijayatiningsih, T. D., \& Fathurrohman, A. (2015).Drill dan Repetition dalam Pelatihan Bahasa Inggris Pemilik Homestay Desa Wisata Kandri Semarang. Paper presented at the $2^{\text {nd }}$ University Research Coloquium
2015.

Retrieved

from http://jurnal.unimus.ac.id/index.php/psn12012010/articl e/view/15145. 